\title{
Perancangan Analytical CRM untuk Mendukung Segmentasi Pelanggan di Institusi Pendidikan
}

\author{
Valentinus Roby Hananto ${ }^{1}$, Agus Dwi Churniawan ${ }^{2}$, Ayouvi Poerna Wardhanie ${ }^{3}$ \\ Institut Bisnis dan Informatika Stikom Surabaya \\ Program Studi Sistem Informasi, Fakultas Teknologi dan Informatika \\ e-mail: 1valentinus@stikom.edu, 2agusdwi@ stikom.edu, ${ }^{3}$ ayouvi@ stikom.edu
}

\begin{abstract}
ABSTRAK. Persaingan untuk meraih pelanggan merupakan salah satu tantangan yang harus dihadapi oleh institusi pendidikan. Berbagai metode diterapkan sebagai upaya untuk meningkatkan daya saing, salah satunya yaitu menggunakan Customer Relationship Mangement (CRM) berupa database pelanggan yang berisi mengenai informasi pelanggan yang terperinci. Perkembangan teknologi manjemen data seperti data warehouse dan data mining menjadi pendukung penerapan CRM yang lebih sistematis dibandingkan sebelumnya. Dalam penelitian ini dijelaskan bagaimana rancangan penerapan analytical CRM untuk mendukung segmentasi pelanggan pada institusi pendidikan. Studi literatur dari berbagai penelitian dilakukan untuk mengetahui teknologi apa saja yang harus dipersiapkan oleh institusi pendidikan dalam penerapan analytical CRM. Selain itu, kami juga melakukan analisis kebutuhan untuk menyesuaikan sistem analytical CRM pada institusi pendidikan. Dengan rancangan terebut, penerapan analytical CRM dapat semakin banyak digunakan dalam mendukung segmentasi pelanggan pada institusi pendidikan.
\end{abstract}

Kata Kunci: Customer Relationship Management, Analytical CRM, segmentasi pelanggan, institusi pendidikan

\section{PENDAhuluan}

Era informasi (Information Age) saat ini telah banyak merubah peta bisnis di semua bidang. Model bisnis yang memiliki keunggulan kompetitif untuk bersaing adalah model bisnis yang menerapakan teknologi informasi, yaitu suatu model bisnis dimana proses bisnisnya dilakukan secara elektronik atau digital melalui jaringan internet. Beberapa sistem aplikasi komputer telah banyak diterapkan di berbagai sektor bisnis, salah satunya pada institusi pendidikan. Perkembangan institusi pendidikan di Indonesia semakin meningkat, lebih dari 3000 institusi pendidikan baik negeri maupun swasta saat ini telah berdiri di Indonesia (Kementrian Pendidikan dan Kebudayaan, 2012). Tingginya tingkat persaingan antar institusi pendidikan mengakibatkan setiap institusi harus dapat mengelola institusinya secara profesional, seperti halnya sebuah perusahaan, sejak dari bagaimana sebuah institusi pendidikan dapat memiliki mutu yang baik, relevansi, sampai dengan daya saing yang tinggi. Perkembangan teknologi informasi dan komunikasi menjadi bagian dari proses-proses tersebut. Saat ini, banyak perguruan tinggi yang telah menerapkan teknologi informasi dan komunikasi yang berkaitan dengan proses peningkatan mutu pelayanan, namun proses tersebut masih belum terintegrasi, ada juga yang masih dilakukan secara manual.

Sebuah organisasi atau institusi pendidikan secara berkesinambungan harus terus menambah cara atau terobosan baru dalam hal berinteraksi dengan pelangganya. Dalam hal ini "pelanggan institusi pendidikan" adalah pemakai produk institusi pendidikan (dunia usaha), pemakai hasil riset yang dilakukan oleh dunia pendidikan (dunia usaha), mahasiswa, peminat/calon mahasiswa, dan alumni yang memerlukan jasa layanan karir. Sedangkan informasi yang dibutuhkan oleh pelanggan menyangkut informasi mahasiswa, peminat/calon mahasiswa, riset, lulusan/alumni dan informasi industri.

Sebuah sistem untuk mengubah data tentang pelanggan menjadi informasi yang berguna bagi perusahaan sangatlah diperlukan. Sebagai jawaban atas tantangan ini, terciptalah sebuah teknologi untuk menganalisis data pelanggan yang sering disebut dengan analytical CRM. Sebagai salah satu alat manajemen pelanggan yang paling dinamis, analytical CRM banyak dimanfaatkan dalam analisis data pelanggan untuk berbagai tujuan yang berbeda. Pada umumnya, sistem ini digunakan untuk mendesain dan melaksanakan kampanye pemasaran yang lebih focus sehingga dapat mengoptimalkan pemasaran.

Analytical CRM memiliki peran penting dalam melakukan segmentasi pelanggan (Straight Marketing, 2010). Sebagai gambarannya, analytical CRM membagi pelanggan menjadi orang yang mungkin masih memanfaatkan layanan perusahaan atau bahkan yang sudah tidak memanfaatkannya lagi serta pemberian informasi yang dapat membantu dalam proses layanan perusahaan. Analytical CRM tidak hanya menentukan profitabilitas atau pelanggan mana yang sangat menguntungkan dari waktu ke waktu tetapi juga memiliki kemampuan melihat pasar khususnya pelanggan secara individual berdasarkan data yang dikumpulkan. Sebagai alat permodelan prediktif, analytical CRM juga dapat membantu perusahaan dalam membandingkan kesuksesan 
ke depan berdasarkan database pengetahuan pelanggan. Seiring waktu, analisis ini juga membantu dalam penyempurnaan keputusan bisnis atas analisis yang telah dibuat sebelumnya. Ketika analytical CRM digunakan dalam bidang penjualan, pemasaran dan jasa, hal tersebut dapat menciptakan hubungan yang lebih baik dan produktif dengan pelanggan, dibandingkan perusahaan yang harus berjuang sendiri untuk mencari tahu apa keinginan atau kebutuhan dari pelanggan. Dengan bantuan alat ini perusahaan akan mengetahui orang mana yang menjadi pelanggan terbaik perusahaan dan bagaimana menemukan prospek perusahaan dengan cepat dan efisien. Sebagai organisasi atau institusi pendidikan yang sedang berkembang, informasi yang di dapatkan melalui analytical CRM ini sangatlah berharga. Analytical CRM membantu dalam mencari tahu informasi pelanggan, profitabilitas pelanggan dan perilaku pelanggan. Setelah mengevaluasi atau mengidentifikasi pelanggan potensial, organisasi akan mendapatkan hasil yang jauh lebih efektif. Menginvestasikan waktu dan uang ke dalam analytical CRM merupakan langkah yang tepat guna mendukung strategi pemasaran ke depannya.

Segmentasi pelanggan bertujuan untuk mengelompokkan pelanggan yang kebutuhan dan perilakunya memiliki kemiripan ke dalam customer segments (Srivastava, 2002). Harapannya adalah setiap customer segment menjadi homogen, paling tidak dari satu perspektif. Umumnya perspektif yang digunakan dalam segmentasi ini adalah berdasarkan nilai dari customer bagi organisasi, atau berdasarkan pola perilaku customer terhadap barang atau jasa yang ditawarkan organisasi. Dengan melakukan segmentasi pelanggan, organisasi dapat menentukan strategi marketing yang lebih terfokus untuk masing-masing segmen. Proses marketing (komunikasi, produk/jasa, program) dapat menjadi lebih terfokus karena masing-masing segmen memang sudah memiliki kemiripan, baik dari segi kebutuhan maupun perilakunya. Sebagai contoh, sebuah perguruan tinggi bisa mengelompokkan pelanggannya (dalam hal ini calon mahasiswa) berdasarkan minat dan bakatnya. Untuk calon mahasiswa yang memiliki minat dan bakat pada satu bidang studi tertentu, perguruan tinggi dapat mengunggulkan program studinya yang terkait dengan bidang studi peminatan dari siswa tersebut. Jika minat ataupun bakat dari siswa adalah di bidang non-akademik, misalnya olahraga, maka perguruan tinggi dapat mempromosikan fasilitas-fasilitas olahraga yang dimiliki maupun prestasinya di bidang olahraga.

Berdasarkan uraian konsep tentang analytical CRM diatas, maka penelitian ini bertujuan untuk mengetahui bagaimana merancang arsitektur analytical CRM guna mendukung segmentasi pelanggan pada pereguruan tinggi khususnya di Institut Bisnis dan Informatika Stikom Surabaya, serta teknologi apa saja yang harus dipersiapkan oleh institusi pendidikan dalam penerapan analytical CRM.

\section{ANALYTICAL CRM}

\subsection{Customer Relationship Management}

Customer Relationship Management merupakan suatu strategi perusahaan yang digunakan untuk memanjakan pelanggan agar tidak berpaling ke pesaing. Dalam hal ini perusahaan memberikan sentuhan pelayanan individual dengan memperlakukan pelanggan sebagai raja. Perusahaan memerlukan database pelanggan yang berisi mengenai informasi pelanggan yang terperinci yang memegang peranan penting dalam CRM. Database dalam industri jasa dapat berisi nama dan alamat pelanggan, pekerjaan serta preferensipreferensi lainnya. Informasi tersebut merupakan aset yang sangat berharga bagi perusahaan dalam menjalin hubungan dengan pelanggan (Gaffar, 2007).

Menurut Hamidin (2008), CRM memiliki tiga elemen kunci yang dikenal dengan "Customer Touch Points", “Applications", dan "Data Stores", yang digambarkan pada Gambar 1.

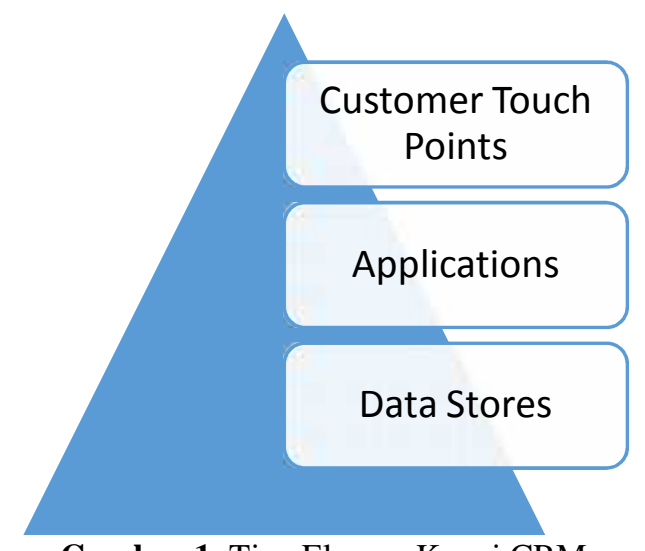

Gambar 1. Tiga Elemen Kunci CRM

Customer Touch Point digunakan oleh organisasi untuk memahami kebutuhan pelanggan saat ini ataupun di masa datang. Ini adalah antar muka yang menghubungkan organisasi dengan pelanggan. Contoh 
media yang digunakan untuk berkomunikasi dengan pelanggan adalah e-mail, website, video conferencing, interactive TV, dan telefon.

Applications merupakan perangkat lunak (software) yang mendukung proses-proses CRM. Contohnya aplikasi yang melayani pemasaran (datamining dan permission marketing software), penjualan (monitoring Customer Touch Pointssoftware), dan layanan (customer care software).

Data Stores berisi data dari setiap aspek pelanggan, dan siklus hidup pelanggan. Contohnya sebuah organisasi menyimpan data transaksi pembelian oleh pelanggan, waktu transaksi ataupun data pelanggan yang melihat produk tetapi tidak membeli. Data tersebut dapat dianalisa dengan menggunakan software.

Banyak paket software diciptakan untuk memudahkan customer relationship, tetapi kebanyakan tergantung dari perolehan, updating dan utilisasi profil individu pelanggan. Profil-profil pelanggan ini biasanya disimpan dalam data warehouse, dan data mining digunakan untuk mengekstrasi informasi yang berhubungan dengan perusahaan dari pelanggan yang bersangkutan. Selanjutnya profil pelanggan ini terhubung secara on line sehingga mereka yang bekerja dalam perusahaan itu dapat menghubungi pelanggan yang bersangkutan. Selain itu Web-based front-ends telah diciptakan sehingga pelanggan dapat menghubungi perusahaan secara online untuk memperoleh informasi mengenai produk atau jasa yang ditawarkan oleh perusahaan itu, memesan order, mengecek status order yang ada, memperoleh jawaban atas pertanyaan yang diajukan atau untuk memperoleh layanan. Paket software CRM membantu perusahaan untuk memasarkan, menjual, dan melayani pelanggan melalui multi media, termasuk Web, call centers, field representatives, business partners, retail and dealer networks. Menurut Jones dalam Hiasdinata (2009), program CRM dalam penerapannya dapat dilihat seperti gambar 2 berikut ini:

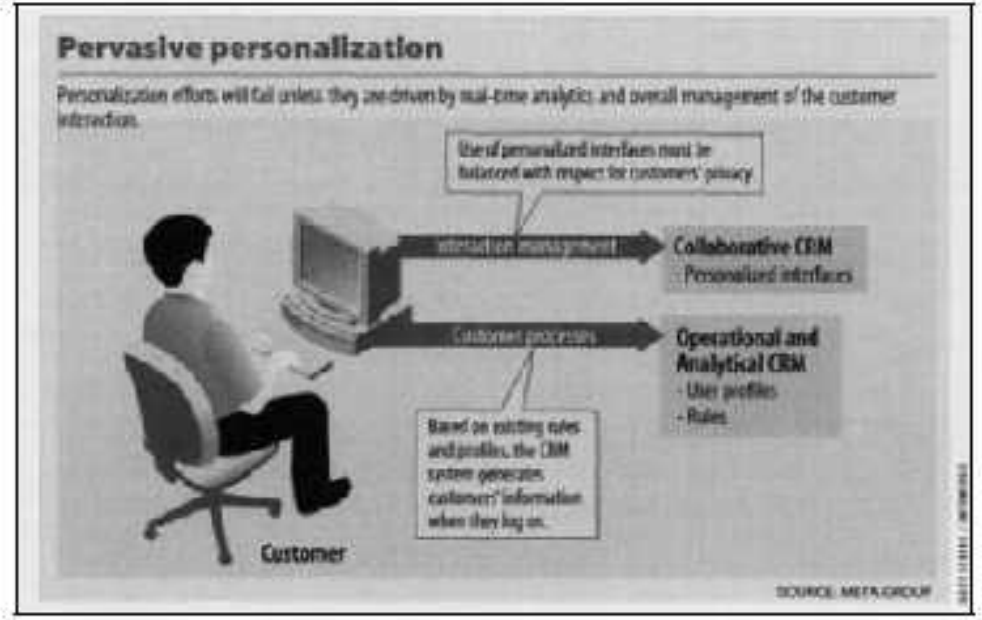

Gambar 2. Program CRM

\subsection{Klasifikasi CRM}

Customer Relationship Management menurut jenisnya dapat dipecah menjadi tiga bagian dengan tugas yang berbeda (Wilde dalam Hiasdinata, 2009) yaitu :

1. Collaborative CRM bertujuan untuk memaksimalkan hubungan dengan customer. Model komunikasi klasik seperti telepon, fax dan pos harus ditunjang dengan teknologi yang modern seperti email dan SMS.

2. Operational CRM bertujuan untuk menyediakan member dari pemasaran, penjualan dan customer service dengan informasi customer dan pasar yang relevan.

3. Analytical CRM berfokus pada pengumpulan, proses dan analisa data customer dengan tujuan untuk mengidentifikasi potensi penjualan, singkatnya data warehouse bisa menjadi tambang emas akan informasi.

Analytical CRM merupakan bagian yang akan menjadi fokus pada penelitian ini, khususnya dalam penerapannya pada perguruan tinggi.

\subsection{Analytical CRM}

Analytical CRM adalah proses analisis data-data yang diperoleh dari Operational CRM. Sekarang ini banyak perusahaan berusaha untuk lebih mengerti tentang pelanggan mereka dengan memberikan respon secara lebih baik dan mengantisipasi kebutuhan mereka. Namun, kebanyakan perusahaan berfokus untuk mengimplementasikan CRM hanya sebatas untuk mengetahui kebutuhan dan keluhan dari pelanggan, yang pada 
praktisnya hanya berkonsentrasi pada komponen operational dan collaborative CRM, sehingga analisis akan pemahaman dan pengenalan terhadap pelanggan belum optimal. Oleh sebab itu, komponen analytical CRM dibutuhkan untuk mengoptimalkan hubungan antara perusahaan dengan pelanggannya.

Menurut Greenberg (2004), analytical CRM adalah tahapan untuk mendapatkan, menyimpan, mengekstrak, memproses, menginterpretasikan, dan melaporkan data pelanggan kepada pengguna. Xu dan Walton dalam Zafareh (2007) menyebutkan bahwa analytical CRM menggabungkan kakas bantu yang dapat memproses data pelanggan untuk mendukung penyediaan informasi pelanggan secara strategis dan mendapatkan pehamaman tentang pelanggan. Analytical CRM adalah sebuah kombinasi dari data warehouse atau data mart yang terintegrasi dengan business inteligence analytical systems (Online Analytical Processing - OLAP) (Zafareh, 2007).

Dengan menerapkan analytical CRM, organisasi diharapkan memiliki kecerdasan bersaing dalam strategi pemasarannya. Sebagai contoh, organisasi dapat memetakan customer segment nya sebagai acuan untuk menentukan metode marketing yang lebih fokus pada masing-masing segmen. Informasi-informasi yang dikumpulkan dari berbagai sumber kemudian dikelola dan dianalisis menggunakan OLAP, menghasilkan pengetahuan yang lebih mengenai pelanggan dan memungkinkan proses marketing yang lebih efektif.

Analytical CRM mampu melakukan segmentasi pelanggan, membedakan pelanggan yang memiliki profitabilitas tinggi dengan tingkat akurasi yang lebih matang, maka return on investement (ROI) akan suatu pelanggan dapat diprediksi dengan baik. Dengan pengetahuan tersebut maka penawaran yang tepat, harga yang tepat dapat ditawarkan pada saat yang tepat, kepada pelanggan yang memang berpotensi untuk membelinya, hal ini akan mengoptimasi pelanggan dan perusahaan. Dengan kombinasi informasi tentang pelanggan dari semua sumber dan sarana informasi vital lainnya yang berinteraksi dengan pelanggan, maka perusahaan dapat memperoleh gambaran yang pasti tentang pelanggan dan perilakunya. Dengan demikian mendukung perusahaan dalam melakukan personalisasi terhadap pelanggan dan menyesuaikan diri seiring dengan kemungkinan perubahan-perubahan yang terjadi dari permintaan pelanggan.

Analytical CRM digunakan juga sebagai alat untuk mengevaluasi profitabilitas pelanggan, berdasarkan segmentasi dari hasil analisa yang kuat, dan meningkatkan ROI dari pelanggan perusahaan. Dengan menganalisa profitabilitas pelanggan, perusahaan dapat melakukan segmentasi pelanggannya berdasarkan tingkat profitabilitasnya sehingga dapat menetapkkan target tingkat penjualannya terhadap masing-masing pelanggan. Langkah selanjutnya adalah menindaklanjuti feedback loop dari hasil analisa yang telah dilakukan untuk menentukan interaksi selanjutnya yang akan dibangun dengan pelanggan.

Ranjan (2009) dalam penelitiannya menyebutkan beberapa contoh penilitian terkait dalam analytical CRM. Ahmed (2004) membuat sebuah model data mining menggunakan prediksi dan klasifikasi untuk menemukan karakteristik dari konsumen yang memiliki kecenderungan untuk pergi. Selain itu, jenis promosi yang efektif untuk menjaring konsumen tertentu juga dapat ditentukan. Tipe-tipe data yang diperlukan dalam aplikasi data mining untuk bisnis berbasis konsumen yaitu:

1. Demografik, seperti usia, jenis kelamin, dan status pernikahan

2. Status ekonomi, seperti gaji dan pekerjaan

3. Detail geografik, seperti kota, provinsi, dan negara

Semua data tersebut beserta jenis data demografik lain dapat digunakan untuk mengelompokkan konsumen ke dalam suatu segmen konsumen yang memiliki kemiripan karakteristik dan kebutuhan produk yang serupa.

Selain penelitian di atas, Qiaohong, dkk (2004) menunjukkan desain analytical CRM berbasis data warehouse. Sap.com (2003) mendiskusikan pentingnya penggunaan analytical CRM di dalam suatu bisnis. Xu dan Walton (2005) juga menjelaskan pentingnya mendapatkan pengetahuan tentang konsumen melalui analytical CRM.

Meskipun banyak penelitian yang sudah dilakukan terkait penerapan aplikasi analytical CRM, namun kebanyakan lebih berfokus pada teknologi data warehouse ataupun metode data mining daripada arsitektur dan implementasinya. Hal ini melatarbelakangi penelitian yang sudah dilakukan oleh Xie (2008) menganai perancangan arsitekur analytical CRM beserta implementasinya pada industry bank. Gambar 3 di bawah ini merupakan arsitektur dari analytical CRM yang sudah diimplementasikan. Secara umum system analytical CRM dapat dibagi menjadi dua bagian, yaitu front-end subsystem yang menyediakan berabagi modul untuk mengontrol data warehouse dan data mining, serta back-end subsystem yang bertujuan untuk menganalisis, memprediksi, dan melaporkan perilaku konsumen. 


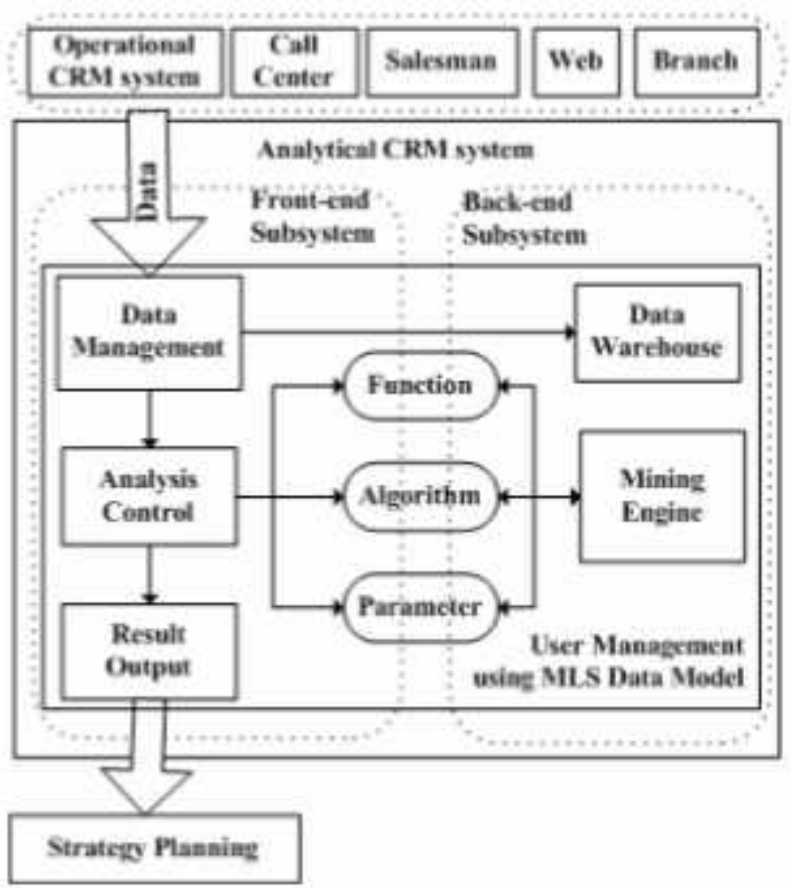

Gambar 3. Arsitektur Analytical CRM pada perbankan (Xie, 2008)

\subsection{Segmentasi Pelanggan}

Salah satu manfaat dari analytical CRM adalah kemampuan untuk mendapatkan profil pelanggan dan mengelompokkan dalam customer segment. Menurut Zafareh (2007), pengelompokan pelanggan dalam segmen ini dapat berdasarkan pada beberapa aspek seperti detail pelanggan, data historis, aktivitas pelanggan, ketertarikan pelanggan, dan kepuasan pelanggan. Informasi ini dibutuhkan untuk lebih mengetahui nilai dari pelanggan dan mendapatkan pemahaman untuk mengetahui perilaku pelanggan.

Proses identifikasi dan definisi dari profil pelanggan tidak hanya penting untuk pelanggan yang ada saat ini, tapi juga untuk calon pelanggan yang prospektif bagi organisasi. Gurau dalam Zafareh (2007) mengemukakan bahwa ketika segmen pelanggan sudah teridentifikasi dan profil perilaku mereka sudah didefinisikan, maka perilaku dari pelanggan baru dapat dicocokkan dengan profil pelanggan yang ada saat ini. Dengan demikian, calon pelanggan baru dapat dikelompokkan pada customer segment yang paling sesuai. Selanjutnya, strategi marketing yang terfokus dapat langsung diimplementasikan sejak awal interaksi dengan calon pelanggan tersebut.

Dalam dunia pendidikan pelanggan dapat dilihat dari berbagai sudut pandang, diantaranya adalah pelanggan adalah pemakai produk institusi pendidikan (dunia usaha), pelanggan adalah pemakai hasil riset yang dilakukan oleh dunia pendidikan, pelanggan adalah mahasiswa, pelanggan adalah peminat/calon mahasiswa dan pelanggan adalah alumni yang memerlukan jasa layanan karir (Hamidin, 2008). Kebutuhan informasi yang akurat dan tepat sasaran menjadi bagian yang penting dalam kesuksesan sebuah implementasi software, khususnya CRM. Informasi yang dibutuhkan yang berhubungan dengan CRM antara lain:

1. Informasi lulusan/alumni, yang meliputi: data lulusan, profil dari menjadi mahasiswa sampai dengan lulus, darimana mahasiswa tersebut berasal (daerah dan sekolah), prestasi kompetensi yang dimiliki, dan profil pekerjaan lulusan.

2. Informasi industri yang meliputi: data industri pemakai produk institusi pendidikan (profil industri), kerja sama yang dilakukan dengan institusi pendidikan, kompetensi kebutuhan industri, informasi layanan karir dan recruitment, potensial riset dan magang staf pengajar dan mahasiswa.

3. Informasi mahasiswa yang meliputi: data perkuliahan (data nilai, jadwal perkuliahan, papan informasi, regristrasi, dan perwalian, serta materi kuliah, serta perwalian).

4. Informasi peminat/calon mahasiswa: peminat yang mendaftar, tidak mendaftar dan mendaftar tidak regristrasi (per wilayah atapun keseluruhan) dan yang melakukan registrasi termasuk stakeholders lainnya seperti: Pemerintah dan masyarakat.

5. Informasi riset yang meliputi: data hasil riset, kerjasama riset dengan industri dan data sumber daya yang dimiliki untuk kerjasama riset. 
6. Informasi manajemen, yang meliputi analisis segmentasi pasar, analisis ancaman dan tantangan pasar, analisis harga dan kebijakan, informasi complaint dan analisis keuangan dan budget.

\section{IDENTIFIKASI KEBUTUHAN ANALYTICAL CRM}

Langkah awal dalam identifikasi kebutuhan adalah pengumpulan data terkait Customer Relationship Management yang sudah ada beserta komponen-komponen pendukungnya. Pengumpulan data tersebut, dilakukan dengan cara wawancara dengan divisi Pemasaran yaitu Kepala Bagian Penerimaan Mahasiswa Baru (Penmaru), selain itu juga dilakukan wawancara dengan Kepala Bagian Administrasi Akademik dan Kemahasiswaan (AAK) dan Kepala Bagian Pengembangan dan Penerapan Teknologi Informasi (PPTI) Stikom Surabaya.

Wawancara yang dilakukan pada Bagian Penerimaan Mahasiswa Baru (Penmaru) berfokus pada penggalian strategi segmentasi pelanggan beserta aspek-aspek segmentasi apa saja yang digunakan. Penelitian yang sudah dilakukan Mardiani (2014) membagi segmentasi mahasiswa berdasarkan 4 dasar, yaitu: segmentasi geografis, segmentasi demografi, segmentasi psikografis, dan segmentasi perilaku. Segmentasi secara demografi dapat dilakukan berdasarkan jenis kelamin,usia, nilai Ujian Nasional (UN), Indeks Prestasi Kumulatif (IPK), pekerjaan orang tua, dan gaji orang tua. Aspek geografi terdiri dari jarak dan akses untuk menuju kampus. Aspek psikografi terdiri dari alasan kuliah, motivasi, dan kebanggan. Sedangkan aspek perilaku terdiri dari sumber info, persepsi mahasiswa terhadap kampus, dan aktivitas setelah kuliah.

Dari hasil wawancara dengan kepala bagian Penmaru, dapat diketahui bahwa beberapa aspek segmentasi pelanggan sudah digunakan. Diantaranya adalah melakukan segmentasi berdasarkan aspek geografis (kota dan provinsi). Data geografis diperoleh dari bagian AAK pada 3 tahun terakhir. Selain itu juga pernah dilakukan pengamatan pada aspek demografi mahasiswa baru yaitu dari jenjang pendidikan nya (SMA / SMK).

Wawancara berikutnya dilakukan dengan kepala bagian Administrasi Akademik dan Kemahasiswaan (AAK) untuk mengetahui sumber data apa saja yang dapat digunakan dalam analytical CRM. Pihak AAK menjelaskan bahwa AAK lebih fokus pada pencatatan data operasional mahasiswa seperti penjadwalan perkuliahan dan entry nilai. Untuk data profil mahasiswa sendiri sudah dicatat Penmaru ketika pendaftaran mahasiswa baru dan semua data tersebut akan terintegrasi dengan data center di bagian PPTI.

Wawancara selanjutnya dilakukan dengan kepala bagian Pengembangan dan Penerapan Teknologi Informasi (PPTI). Sebagai bagian yang bertanggung jawab untuk semua sistem informasi dan data yang ada di Stikom Surabaya, peneliti berusaha untuk menggali sumber-sumber data lain yang dapat digunakan untuk analytical CRM. Salah satunya adalah dengan melakukan analisis pada website Stikom dengan dukungan sistem Google Analytics. Hasil dari Google Analytics dapat digunakan dalam analisis aspek segmentasi pelanggan, seperti data geografis dari pengunjung website Stikom Surabaya maupun website program studi. Aspek psikografis juga dapat dianalisis misalnya dengan melihat sistem maupun perangkat yang digunakan oleh pengakses website Stikom. Selain itu juga dapat dilakukan analisis data dari hasil survey yang dilakukan Penmaru untuk mahasiswa baru, misalnya aspek demografis yaitu tingkat pendapatan orang tua. Pengumpulan data juga dilakukan dengan melakukan observasi lapangan, yaitu melihat bagaimana proses pemasaran yang dilakukan oleh Stikom Surabaya sampai dengan proses penerimaan mahasiswa baru.

Setelah melakukan tahap wawancara dan observasi, peneliti melakukan identifikasi masalah yaitu penetapan aspek-aspek segmentasi pelanggan dan sumber data yang dapat diperoleh dari aspek segmentasi tersebut. Adapun hasil dari identifikasi masalah yang peneliti temukan dijabarkan pada Tabel 1.

Tabel 1. Sumber data segmentasi pelanggan

\begin{tabular}{|l|l|l|}
\hline Nomor & \multicolumn{1}{|c|}{ Aspek - Aspek Segmentasi } & \multicolumn{1}{c|}{ Sumber Data } \\
\hline 1 & Geografis & $\begin{array}{l}\text { Data Mahasiswa Baru (AAK) } \\
\text { Web Analisis (PPTI) }\end{array}$ \\
\hline 2 & $\begin{array}{l}\text { Demografis } \\
\text { Pendidikan } \\
\text { Pendapatan }\end{array}$ & $\begin{array}{l}\text { Data Mahasiswa Baru (AAK) } \\
\text { Angket Penmaru }\end{array}$ \\
\hline 3 & $\begin{array}{l}\text { Psikografis } \\
\text { Kelas Sosial \& Gaya Hidup }\end{array}$ & $\begin{array}{l}\text { Angket Penmaru } \\
\text { Web Analisis (PPTI) }\end{array}$ \\
\hline 4 & $\begin{array}{l}\text { Perilaku } \\
\text { Sikap } \\
\text { Pengetahuan }\end{array}$ & $\begin{array}{l}\text { Kemahasiswaan } \\
\text { Angket Penmaru }\end{array}$ \\
\hline
\end{tabular}


Dari beberapa sumber data tersebut, peneliti sudah melakukan observasi terhadap beberapa sumber data di antara nya analisis web menggunakan Google Analytics. Analisis web ini diterapkan pada website Stikom Surabaya (http://www.stikom.edu) maupun website program studi. Sebagai contoh berikut ini adalah beberapa hasil dari analisis website prodi S1 Sistem Informasi (http://si.stikom.edu). Gambar 4 menunjukkan hasil analisis pengunjung website prodi berdasarkan aspek geografi (kota).

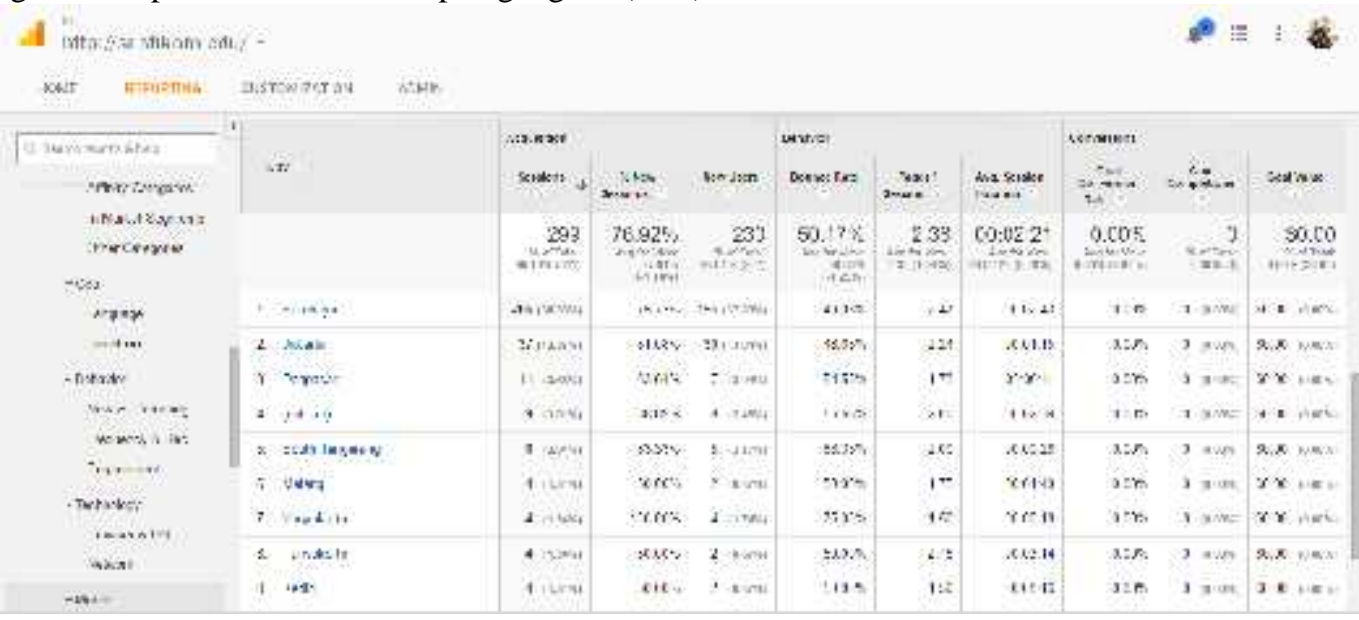

Gambar 4. Google Analytics aspek geografis

Selain aspek geografis, hasil dari Google Analytics juga dapat menunjukkan informasi pengunjung dari aspek psikografis, yaitu device yang digunakan untuk mengakses website, maupun aspek demografis (jenis kelamin).

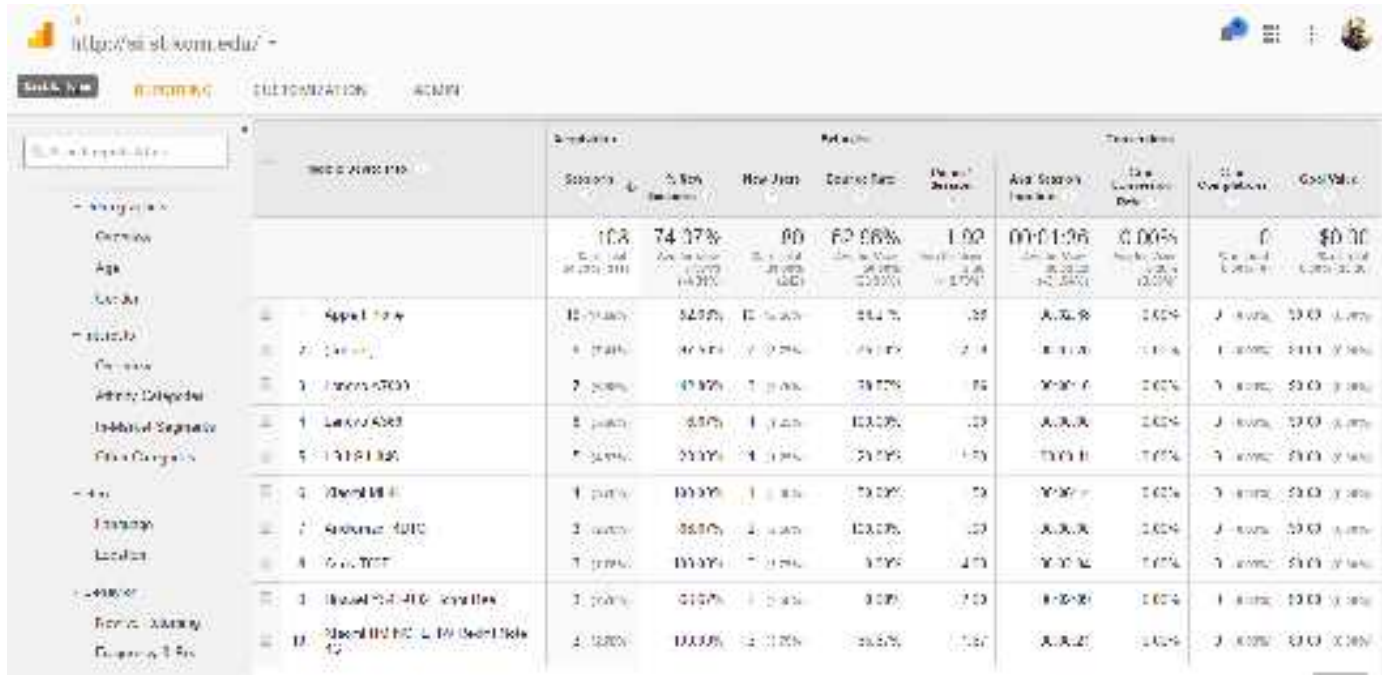

Gambar 5. Google Analytics aspek psikografis (mobile device) 


\section{Gender \\ $100 \%$ of total sessions}

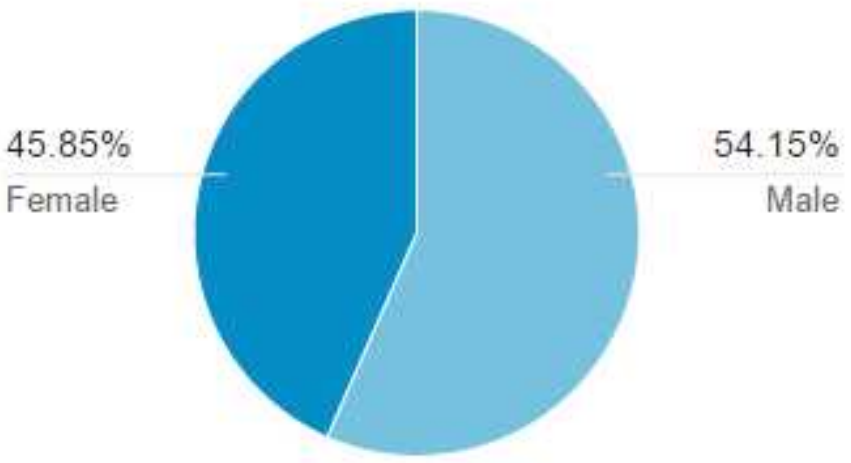

Gambar 6. Google Analytics aspek demografis (jenis kelamin)

\section{RANCANGAN ANALYTICAL CRM}

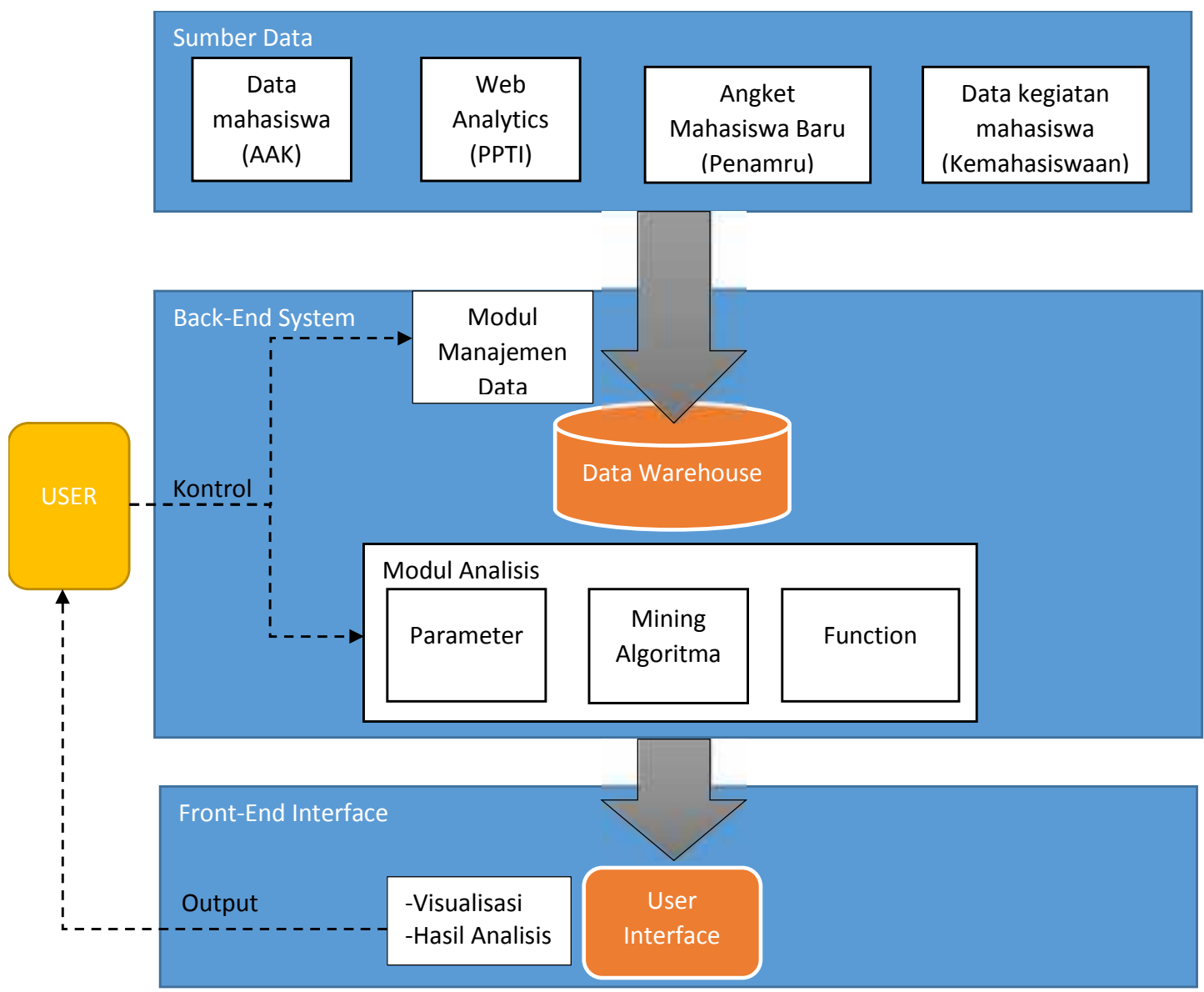

Gambar 7. Rancangan Analytical CRM 
Pada tahap ini, akan dibahas tentang back-end system yang dibutuhkan dalam analytical CRM. Pada gambar di atas, dapat dilihat beberapa sumber data yang dibutuhkan untuk analytical CRM. Tiga entitas utama yang digunakan pada CRM meliputi Customer, Product, dan Channel (Srivastava, 2002). Pada umumnya informasi terkait tiga entitas ini tersebar pada banyak database operasional. Sumber data berasal dari sistem operasional, dalam studi kasus ini contohnya adalah data mahasiswa, data angket mahasiswa baru, data kegiatan mahasiswa, dan web analytics (PPTI). Data-data ini berasal dari sistem yang berbeda, sehingga memiliki format dan tipe data yang tidak seragam. Ketidakseragaman ini akan diproses ke dalam back-end system melalui sebuah modul manajemen data yang dapat berfungsi untuk extract, clean, filter, transform, dan mengelola data dalam jumlah yang besar dari beragam sistem. Terdapat sebuah kontrol dari user untuk mengatur setiap kali proses manajemen data ini dilakukan dan data apa saja yang digunakan. Kemudian semua data ini akan masuk ke dalam satu data warehouse yang merupakan sebuah repositori data suatu organisasi (Xie, 2008).

Selanjutnya untuk melakukan kontrol terhadap proses analytics pada back-end system, dibuatlah modul untuk kontrol analisis. Setelah sebelumnya modul data manajemen menyiapkan data ke dalam data warehouse, user selanjutnya memilih fungsi analisis yang akan dijalankan. Back-end system akan mempersiapkan model dan proses analisis yang sesuai. User dapat menentukan beberapa parameter yang digunakan sebagai batasan dari algoritma data mining ataupun analytics yang digunakan. Selanjutnya, hasil analisis akan ditampilkan atau divisualisasikan melalui sebuah user interface. Hasil ini akan digunakan sebagai pendukung dalam pemahaman segmentasi pelanggan dan pengambilan keputusan.

Generasi berikutnya dari analytical CRM mengharuskan perusahaan untuk merentangkan spektrum analitis dan fokus untuk melihat ke masa depan. Tekanan waktu untuk pemasaran, dikombinasikan dengan ledakan data, memaksa banyak organisasi berjuang untuk tetap kompetitif. Ditambah dengan kebutuhan untuk lebih proaktif, organisasi memfokuskan usaha analisis mereka untuk menentukan apa yang akan terjadi, apa yang bisa mereka lakukan untuk mewujudkannya, dan akhirnya untuk mengotomatisasi seluruh proses. Data mining sekarang dapat dipandang sebagai kebutuhan analitis. Fokus utama dari data mining adalah untuk menemukan pengetahuan, yang sebelumnya tidak diketahui, memprediksi kejadian masa depan dan mengotomatisasi analisis data set yang sangat besar. Proses data mining terdiri dari sejumlah langkah. Pertama data yang dikumpulkan harus diproses untuk dapat dilakukan data-mining. Ini memerlukan sejumlah langkah untuk membersihkan data, menangani ketidaksesuaian dalam format, struktur, serta semantik, dan normalisasi dan integrasi. Setelah data telah dibersihkan, algoritma mining berbagai data dapat diterapkan untuk mengekstrak model dari itu. Sejumlah teknik data mining telah dikembangkan, dan salah satu yang akan diterapkan tergantung pada tujuan tertentu. Setelah model telah dikembangkan, dapat digunakan untuk dua jenis tujuan. Pertama adalah untuk memperoleh pemahaman tentang perilaku saat ini dari pelanggan. Sebuah model yang digunakan untuk tujuan ini disebut model deskriptif. Kedua adalah dengan menggunakan model untuk membuat prediksi tentang perilaku masa depan pelanggan. Sebuah model yang digunakan untuk tujuan ini disebut model prediktif. Model deskriptif, diambil dari perilaku masa lalu, digunakan sebagai titik awal dari mana model prediksi dapat dibangun. Pendekatan seperti itu telah ditemukan cukup sukses, seperti yang didasarkan pada asumsi bahwa perilaku masa lalu adalah prediktor yang baik dari perilaku masa depan dengan penyesuaian yang diperlukan.

\section{KESIMPULAN}

Penerapan Customer Relationship Management (CRM) merupakan salah satu upaya untuk meningkatkan daya saing suatu perusahaan. Namun, makalah penelitian tentang arsitektur sistem dan teknologi implementasi untuk analytical CRM yang telah diterbitkan masih relatif sedikit. Analytical CRM dapat menemukan pengetahuan dari sejumlah besar data dan memainkan peran penting dalam mendukung keputusan. Dalam penelitian ini telah dirancang sebuah arsitektur praktis untuk membangun sistem analytical CRM. Arsitektur ini tidak hanya memberikan transisi yang mudah dari konsep analisis dalam teori CRM menjadi praktis, tetapi juga merelasikan modul-modul dari sistem analytical CRM bersama-sama dengan cara yang koheren. Rancangan analytical CRM ini dapat diterapkan di institusi pendidikan sehingga dapat diperoleh database pelanggan yang kuat, memberikan analisis segmentasi pelanggan, sehingga dapat membantu dalam interaksi dengan pelanggan yang lebih targeted dan customized. Dengan demikian, diharapakan sebuah institusi pendidikan dapat memiliki keunggulan kompetitif. 


\section{DAFTAR PUSTAKA}

[1] Gaffar, V. 2007. CRM dan MPR Hotel (Customer Relationship Management and Marketing Public Relations), Cetakan 1. Bandung: Alfabeta.

[2] Greenberg, P. 2004. CRM at the Speed of Light: Essential Customer Strategies for the 21st Century (Third Edition). London \& New York: McGraw-Hill.

[3] Hamidin, D. 2008. Model Customer Reltionship Mangement (CRM) di Institusi Pendidikan. Seminar Nasional Aplikasi Teknologi Informasi 2008. Yogyakarta.

[4] Hiasdinata. 2009. Customer Relationship Management (CRM) dan aplikasinya dalam industri manufaktur dan jasa.

[5] Kementrian Pendidikan dan Kebudayaan. 2012. Indonesia Educational Statistics In Brief. Jakarta.

[6] Mardiani, I. E. 2014. Analisis Segmentasi dan Targeting Mahasiswa Fakultas Ekonomi Universitas Esa Unggul. Jurnal Ekonomi, Volume 5 Nomor 2, November 2014.

[7] Ranjan, J. 2009. Role of Analytical CRM in CRM Systems: Importance and Benefits. Management \& Change, 13.

[8] Srivastava, Jaideep; Wang, Jau-Hwang; Lim, Ee Peng; and Hwang, San-Yih. 2002. A Case for Analytical Customer Relationship Management. 6th International Conference on Knowledge Discovery and Data Mining (PAKDD-02). Research Collection School Of Information Systems.

[9] Straight Marketing. 2010. Analytical CRM. Retrieved from StraightMarketing.com: http://www.straightmarketing.com/analytical_customer_relationship_management.asp

[10] Xie, Yaya. 2008. A Process Driven Architecture of Analytical CRM Systems with Implementation in Bank Industry. International Journal of Intelligent Information Technology Application 1:1 (2008) 48-52

[11] Zafareh, J. T. 2007. The Role of Analytical CRM in Maximizing Customer Profitability in Private Banking. Lulea: Lulea University of Technology. 